OnLine Journal of Biological Sciences 9 (3): 75-80, 2009

ISSN 1608-4217

(C) 2009 Science Publications

\title{
Microanatomy and Histochemistry of the Salt Glands of the Kentish Plover, Charadrius alexandrines (Aves, Charadriidae)
}

\author{
Bashir M. Jarrar \\ Department of Clinical Laboratory Sciences, College of Applied Medical Sciences, \\ Al-Jouf University, P.O. Box (2014), Skaka-Al-Jouf, Saudi Arabia
}

\begin{abstract}
Problem statement: Histological and histochemical investigations on the salt glands of birds are very limited. The present study was performed to characterize the microanatomy and histochemistry of the salt glands of the Kentish plover (Charadrius alexandrines). Approach: Salt glands of the bird under study were fixed, dehydrated, cleared, impregnated and blocked out by paraffin wax. Paraffin sections were utilized in histological and histochemical examinations to characterize the structure and chemical contents of these glands. Results: The Kentish plover had a well developed bilateral seromucous salt glands lie in the supraorbital depression of the frontal bone. Each gland is about $0.18 \mathrm{~g}$ and had lobular arrangement consisted of one cell thick secretory tubules enmeshed in tiny blood capillaries. The tubules radiate from central canals that drain in a main duct of 3-4 $\mathrm{mm}$ in length and opens into the external nares. The secretory tubules were lined by a single layer of principal cells and opens in intercalated ducts followed by striated ducts. The employed histochemical tests indicated that seretory tubules elaborate proteins and acid mucosubstances but are devoid of glycogen and neutral mucosubstances while the intertubular stroma showed metachromatic, alcianophilic and PAS reactivity. Conclusion/Recommendations: The results of the present study revealed that salt glands of Kentish plover are active adaptive tool of osmoregulation to control the amount of water needed by this bird. More research is needed to understand the adaptation of the seabirds to the physiological stress of the salt load.
\end{abstract}

Key words: Saline tolerance, waterbirds, osmoregulation, mucosubstances

\section{INTRODUCTION}

Drinking seawater and feeding on saline marine food put physiological stress on marine birds to reduce the salt load and to eliminate excess electrolytes. Birds inhabit freshwater ponds possess significantly small or inactive salt glands while seabirds who have limited or no excess to freshwater are equipped with well developed specialized salt glands $s^{[1,2]}$. These glands allow marine birds to maintain water and ion concentration balance by excreting salt from seawater they ingest with their food. The concentrating ability of salt can reach from five to eight times ${ }^{[3]}$.

There are several species of plovers in Saudi Arabia with the Kentish plovers (Charadrius alexandrinus) is the most common. It is seen throughout the year in the Gulf coast of Saudi Arabia, Jizan and on the Farasan Islands with increasing presence in most subtropical and tropical parts of the world. This species breeds on sandy coasts and brackish inland lakes and is uncommon on fresh water. It feeds on aquatic invertebrates including crustaceans, mollusks, marine worms, insects and brine shrimps ${ }^{[4]}$.
Some of the morphology of avian salt glands has been described ${ }^{[5-7]}$, while histological and histochemical investigations on the salt glands of birds are very limited $^{[2]}$. However, the salt glands of the Kentish plover (Charadrius alexandrinus) are not identified. With this objective, the present study was performed to characterize the microanatomy and histochemistry of the salt gland of Charadrius alexandrinus.

\section{MATERIALS AND METHODS}

Six adults of the Kentish plovers (Charadrius alexandrinus) of the same age were killed by decapitation. Both salt glands were quickly removed from each bird, weighed and quickly immersed in neutral buffered formalin and Gendre's fluid. Tissue specimens were then dehydrated in ethanol, cleared in chloroform, impregnated with molten paraffin wax and finally embedded and blocked out. Tissue sections (4$5 \mu \mathrm{m})$ were stained according to Pearse $^{[8]}$ with haematoxylin and eosin (H and E) and Mallory's trichrome methods. Other paraffin sections were then utilized in the following histochemical reactions: 
Glycogen and neutral mucosubstances: Best's carmine technique, Periodic Acid-Schiff (PAS) technique, PAS after $\alpha$-amylase digestion, PAS after acetylation blockade, PAS after acetylationsaponification and PAS after phenylhydrazine treatment $^{[8]}$.

Acid mucosubstances: Alcian Blue (AB) at $\mathrm{pH} 2.5$ and $1.0^{[8]}$.

Distinction between acidic and neutral mucosubstances: $\mathrm{AB}$ ( $\mathrm{pH}$ 2.5)-PAS and $\mathrm{AB}$ ( $\mathrm{PH} 1.0)-$ $\operatorname{PAS}^{[8]}$.

Distinction between sulfomucins and sialomucins: Aldehyde Fuchsin (AF) and AF-AB, pH 2.5, weak $\left(25^{\circ} \mathrm{C}, 16 \mathrm{~h}\right)$, mild $\left(37^{\circ} \mathrm{C}, 4 \mathrm{~h}\right)$ or strong $\left(60^{\circ} \mathrm{C}, 4 \mathrm{~h}\right)$ methylation-saponification- $\mathrm{AB}, \mathrm{pH} 2.5$; acid hydrolysis $\left(0.1 \mathrm{~N} \mathrm{HCl}, 60^{\circ} \mathrm{C}, 4 \mathrm{~h}\right)-\mathrm{AB}(\mathrm{pH} 2.5)$; Toluidine Blue (TB) buffered at $\mathrm{pH} 1.7$ and 3.4; Critical Electrolyte Concentration (CEC) technique for extinction of alcianophilia at $\mathrm{pH} 5.6$ in the presence of gradual concentration of $\mathrm{Mg}^{++[8]}$.

Enzymes digestion tests: Diastase-PAS technique; neuraminidase (Sialidase, Vibrio cholerae, type V)-AB at $\mathrm{pH}$ 2.5, hyaluronidase (testicular)- $\mathrm{AB} \mathrm{pH} 2.5$, neuraminidase-TB $(\mathrm{pH} 3.7)$ and hyaluronidase-TB $\mathrm{pH}$ $2.0^{[8]}$. Control sections were incubated in the buffer solutions without the enzymes.

Proteins tests: Mercuric bromophenol blue and ninhydrin-Schiff methods ${ }^{[8]}$ were used for detection of proteins.

\section{RESULTS}

The Kentish plovers (Charadrius alexandrinus) has bilateral tubular salt glands lie immediately under the skin in the supraorbital depression of the frontal bone (Fig. 1). At the anterior end of each gland is a duct of 3$4 \mathrm{~mm}$ in length and opens into the external nares. Each gland has a pear like shape with a length of $14 \mathrm{~mm}$ and a width of $2 \mathrm{~mm}$ in the anterior pointed part and $5 \mathrm{~mm}$ in the posterior broad part. The average weight of the bilateral glands is about $0.36 \mathrm{~g}$.

Each gland consists of many concentric polygonal lobules (Fig. 2) arranged in rows and separated by richly vascularised interlobular connective tissue. Each lobe is made of a mass of prenchymal branched secretory tubules radiate out from a central canal and enmeshed in one cell layer of blood capillaries (Fig. 3).

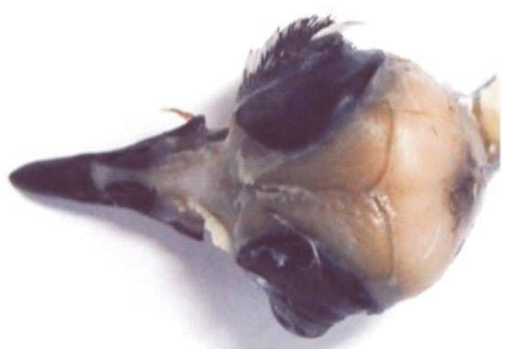

Fig. 1: Light photograph showing the salt glands of Kentish plovers (Charadrius alexandrinus) showing frontal view of the bilateral salt glands

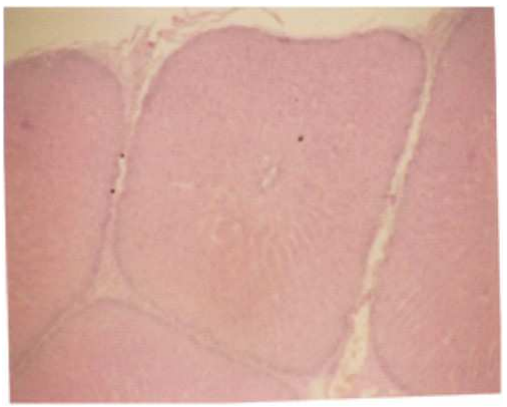

Fig. 2: Light micrograph sections in salt gland of Kentish plovers (Charadrius alexandrinus) showing: Secretory lobule, $\mathrm{H}$ and $\mathrm{E}$

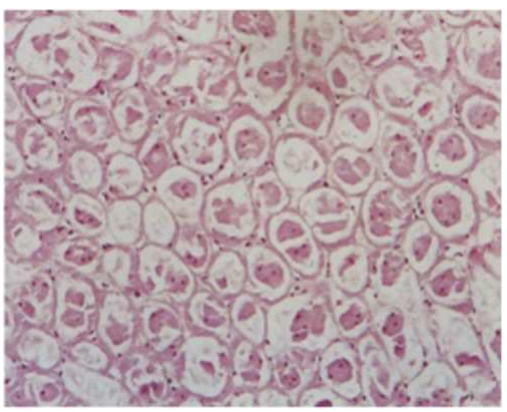

Fig. 3: Secretory tubules, $\mathrm{H}$ and $\mathrm{E}$

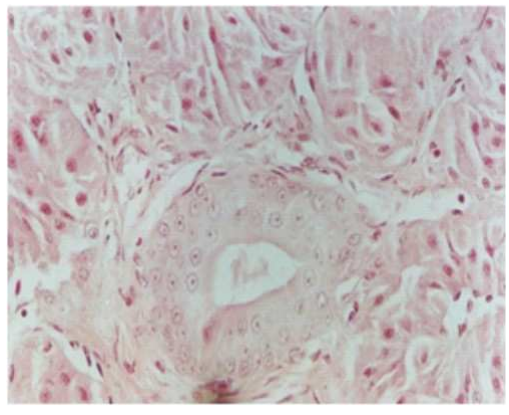

Fig. 4: The epithelial lining of the central canal, $\mathrm{H}$ and $\mathrm{E}$ 
The ductal system of each lobe opens in central canals (Fig. 4) that drain in a main duct (Fig. 5) which is lined by stratified cuboidal epithelium and leads to the anterior of the nasal cavity. The secretory tubules are lined by a single layer of principal columnar cells surrounding a narrow lumen while the peripheral tubules are lined with short columnar and round basal cells. The columnar cells have basal nuclei while small round basal cells interspersed randomly among the columnar excretory ones. The secretory tubules open in intercalated ducts followed by striated ones (Fig. 6). The intercalated ducts are lined by single layer of low cuboidal cells while the striated ones are lined by simple epithelium consisting of cuboidal to columnar cells.

Each gland is supplied by large branches of blood vessels where numerous arterial branches enter the intertubular spaces and distribute to lobes via highly vascularized interlobular connective tissue (Fig. 7). Lobular arterioles penetrate to the secretory tubules area before dividing into capillaries supplying the secretory epithelium and run radially towards the lobe periphery.

The secretory tubules of the glands under study reacted negatively to PAS and Best's carmine techniques but they responded positively to ninhydrin-Schiff and mercuric bromophenol blue for protein detection (Fig. 8 and 9). Also the glands responded positively to $\mathrm{AF}-\mathrm{AB}$ at $\mathrm{pH} 2.5$ (Fig. 10).

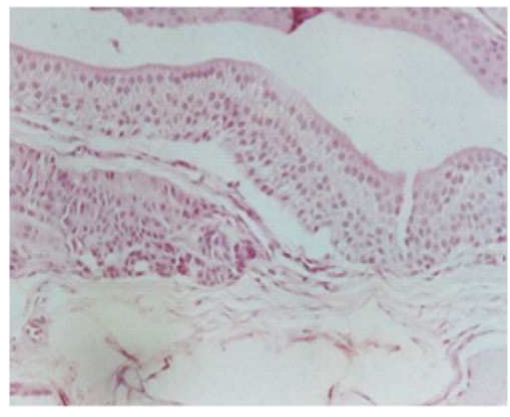

Fig. 5: The epithelial lining of the main duct, $\mathrm{H}$ and $\mathrm{E}$

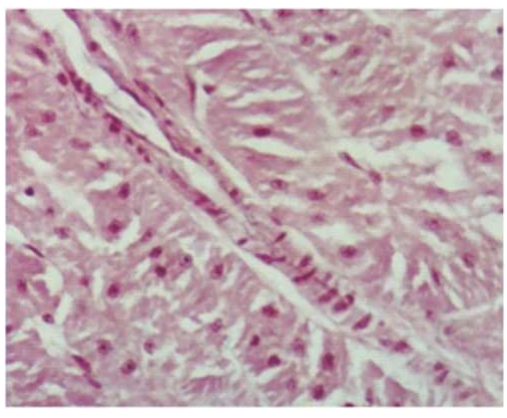

Fig. 6: Striated duct, $\mathrm{H}$ and $\mathrm{E}$
These tubules showed alcianophilia at pH 2.5 (Fig. 11) and to a lesser extent at $\mathrm{pH} 1.0$ and reacted positively with the CEC at 0.2 and $0.3 \mathrm{M} \mathrm{Mg}^{++}$(Fig. 12).

The intertubular stroma of the glands reacted positively to PAS. This reactivity withstood both $\alpha$ amylase digestion and phenylhydrazine treatment, but was completely blocked by acetylation and was partly restored by deacetylation-PAS sequential techniques. Also the glandular stroma showed weak $\alpha$ metachromasia at $\mathrm{pH} 3.4$ and ortochromatic reaction at $\mathrm{pH} 1.7$.

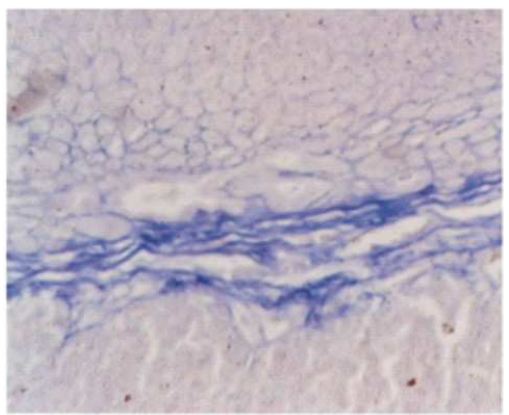

Fig. 7: The intertubular connective tissue, Mallory's trichrome

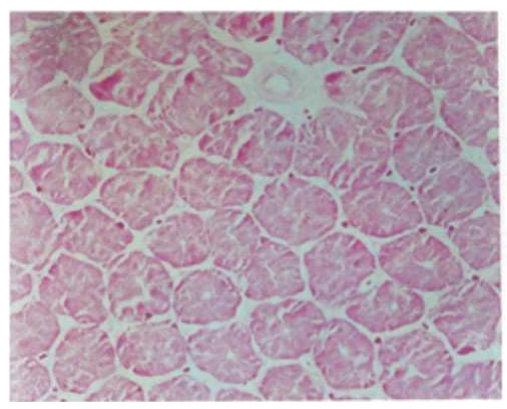

Fig. 8: Secretory tubules stained with ninhydrin-Schiff

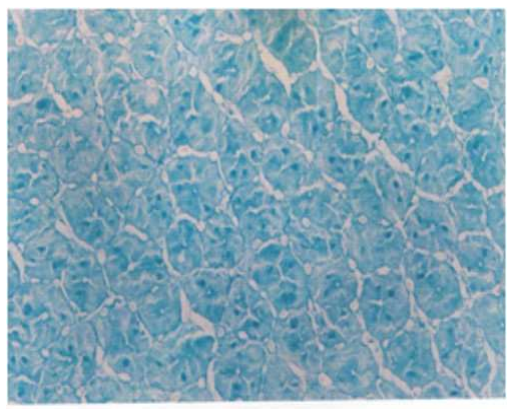

Fig. 9: Secretory tubules stained with mercuric bromophenol blue 


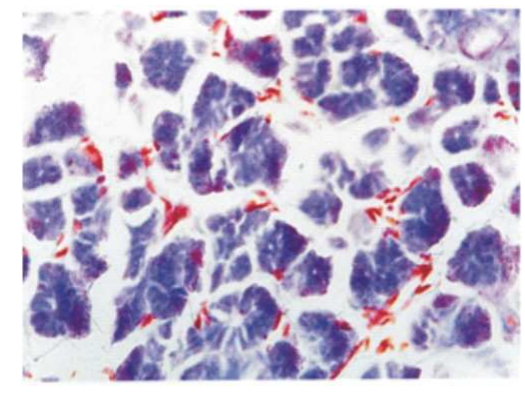

Fig. 10: Secretory tubules stained aldehyde fuchsinalcian blue ( $\mathrm{pH} 2.5)$

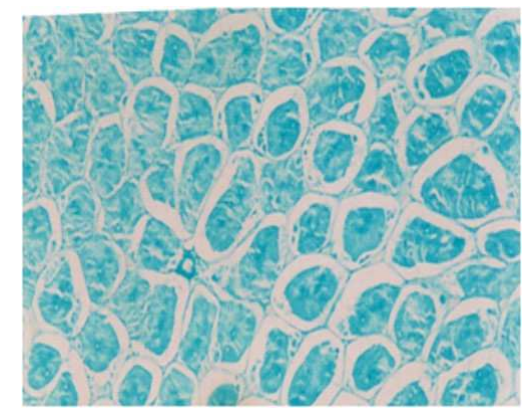

Fig. 11: Secretory tubules stained with alcian blue (pH 2.5)

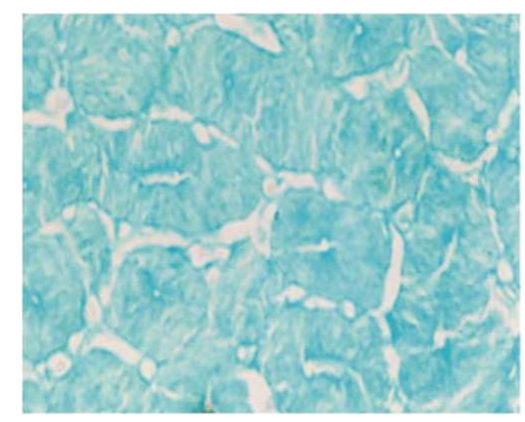

Fig. 12: Secretory tubules stained with CEC at $0.2 \mathrm{M} \mathrm{Mg}^{++}$

\section{DISCUSSION}

Marine birds have two routes of sodium chloride excretion, the renal and the extrarenal salt excretion ${ }^{[9]}$. Saline tolerance in these birds is determined by the efficiency of the reabsorption of water and sodium ions by the renal tubules and the secretion of sodium by the salt glands ${ }^{[10]}$. Cephalic glands of the extant marine sauropsides modified for salt excretion as nasal in birds and lizards, sublingual and premaxillary in snakes, lacrimal in turtles and lingual in crocodiles ${ }^{[11-13]}$. Salt glands are considered as modified nasal glands controlled by the nervous system enable birds with marine habitat to excrete excess sodium chloride ${ }^{[14,15]}$.

Kentish Plovers feeds on small crustaceans, mollusks, marine worms, aquatic insects, brine larvae, brine shrimps and aquatic seeds. Feeding on these either by pecking them from the beaches, salt flats, salt bonds and saltmars, might ingest large amount of hypertonic water and incur deleterious salt load. The structure of the salt glands of the Kentish plover as seen by the results of the present study can be considered as an adaptive tool of osmoregulation to control the amount of water needed by this bird. Salt glands are best developed and quite functional in birds live in marine habitat but are poorly developed, with some exceptions in terrestrial birds and those inhibit freshwater ponds ${ }^{[16-19]}$. Some terrestrial birds such as Roadrunnes and Savana Hawks have active salt glands that can minimize water loss by hypertonic secretions in response to their protein rich diet. Also some desert birds that consume little water have functional salt glands that are stimulated in response to high temperature ${ }^{[18,20]}$. Efficient salt glands have been reported in penguins, the greater flamingo Phoenicopterus rubber roseus and the duck Anas platyrhnches ${ }^{[2,5,6,18,21]}$.

Several studies correlated the efficiency of salt gland with the gland size, the number and length of the secretory lobules ${ }^{[10,13]}$. The number of the secretory lobules together with the large surface area of the array of secretory tubules together with the well developed ductal system seen in the salt gland of Charadrius alexandrinus might indicate efficiency in salt concentrations. Some studies indicated that the salt glands are stimulated by water loaded salt while their size and ductal system are determined by salinity of the drinking water to which the bird is exposed $\mathrm{d}^{[5,22-24]}$.

The activity of salt glands is also related with the bird behavior and seasonal variation. Bennett and Hughes $^{[25]}$ concluded that the salt glands of many species of ducks hypertrophy when they switch seasonally from fresh water to saline habitat. This is in agreement with the findings in the rectal salt glands of some marine mammals. Oguri ${ }^{[26]}$ reported small rectal salt glands in the bull shark, Carchahinus leucas that inhabits fresh-water environment in comparison with other species from a marine habitat. Kentish plover moves between lakeshore and salt marsh according to food abundance and breeding season which may affect the size and development of their salt glands ${ }^{[27]}$.

The results of the present investigation show that the salts glands of the Charadrius alexandrinus have lobular arrangement and consist of thousands of one cell thick secretory tubules enmeshed in tiny blood 
capillaries. These together form a proper barrier between the salty fluid within the secretory tubules and the blood stream of the blood capillaries. Some investigators reported that the flow in the secretory tubules of the salt glands is in the opposite direction to that of the capillaries and thus constitutes a countercurrent arrangement ${ }^{[12]}$.

A tentative interpretation of the types of mucosubstances in the salt glands of Charadrius alexandrinus can be made from the results of the different histochemical reactions used in the present investigation and from the classification of mucosubstances proposed by Gabe and Saint-Girons ${ }^{[28]}$ and Pearse ${ }^{[8]}$. Neutral mucosubstances are PAS positive, diastase resistant, as well as unstainable by cationic dyes. Acetylation produces derivatives of primary and secondary amines which prevent 1,2 glycol groups, from reacting with PAS indicating the presence of neutral mucosubstances or sialic acid, separately or simultaneously. Alcian blue is generally considered as being specific for identifying acid mucosubstances where alcianophilia at $\mathrm{pH} 2.5$ and 1.0 is specific for sialomucins and sulformucins respectively. Sialomucins can be identified by alcianophilia at $\mathrm{pH} 2.5$ which is partially lost following acid hydrolysis and completely removed after neuraminidase digestion, but neuroaminidase did not affect the staining of sulfated mucosubstances. A loss of alcianophilia after hyaluronidase digestion is due to the removal of hyaluronic acid and chondroitin sulfates. Methylation blocks subsequential staining of simple mucosubstances by esterification of carboxyl groups and complex sulfated mucosubstances desulphation. Subsequent saponification after methylation will restore the staining of carboxyl groups. The mucosubstances that are stained at $0.1 \mathrm{M} \mathrm{MgCl}_{2}$ in the $\mathrm{CEC}$ reaction, but not at $0.2 \mathrm{M} \mathrm{MgCl} 2$ are believed to contain carboxyl group and no sulfate groups. Sulfated mucosubstances, on the other hand, stain strongly and selectively at $0.2 \mathrm{M} \mathrm{Mg}^{++}$but lose their alcianophilia at different levels with increasing $\mathrm{MgCl}_{2}$ concentration. Accordingly, the salt glands of the Kentish plover (Charadrius alexandrinus) are of seromucous type with secretory tubules elaborate proteins, sialomucins and acid sulfomucins but devoid of glycogen and neutral mucosbstances.

\section{CONCLUSION}

The results of the present study revealed that salt glands of Kentish plover are active adaptive tool of osmoregulation to control the amount of water needed by this bird. More research is needed to understand the adaptation of the seabirds to the physiological stress of the salt load.

\section{ACKNOLEDGMENT}

I gratefully acknowledge the help of Dr. Mansour Almansour for providing me with the birds used in the present study.

\section{REFERENCES}

1. Cornelius, S.E., 1982. Wetland salinity and salt gland size in the redhead Aythya Americana. Auk, 99: 774-778. http://www.jstor.org/stable/4086189

2. Almansour, M.I., 2007. Anatomy, histology and histochemistry of the salt glands of the greater flamingo Phoenicopterus rubber roseus (Aves, Phoenicopteridae). Saudi J. Biol. Sci., 14: 137-144. http://www.saudibiosoc.com/SJBS/14-2/abstracts/2.html

3. Sabat, P., J.M. Farina and M.S. Gamboa, 2003. Terrestrial birds living on marine environments: Does dietry composition of Cinclodes nigrofumosus (Passeriformes: Furnariidae) predict their osmotic load?. Rev. Chil. Hist. Nat., 76: 335-343. DOI: 10.4067/S0716-078X2003000200017

4. Porter, R.F., S. Christensen and P. Shiermaker-Hansent, 1996. Field Guide to the Birds of the Middle East. Princeton University Press Inc., San Diego, ISBN: 10: 0856610763, pp: 480.

5. Marshall, A.T., P. King, R.J. Condron and J.G. Phillips, 1987. The duct system of the avian salt gland as a transporting epithelium: Structure and morphology in the duck Anas platyrhynchos. Cell Tiss. Res., 249: 179-188.

http://www.ncbi.nlm.nih.gov/pubmed/3040252

6. Hossler, F.E. and K.R. Oslon, 1990. Microvasculature of the nasal salt gland of the duckling, Anas platyrhynchos: Quantitative responses to osmotic adaptation and deadaptation studied with vascular corrosion casting. J. Exp. Zool., 254: 237-247. http://www.ncbi.nlm.nih.gov/pubmed/2189020

7. Butler, D.G., 1980. Functional nasal salt glands in adrenal ectomized domestic ducks (Anas platyrhynchos). Gen. Comp. Endocrinol., 40: 15-26. http://www.ncbi.nlm.nih.gov/pubmed/7353783

8. Everson Pearse, A.G., 1985. Histochemistry: Theoretical and Applied: Analytical Technology. Vol. 2, 4th Revised Edn., Churchill-Livingstone, Edinburgh, ISBN: 10: 0443029970, pp: 624.

9. Braun, E.J., 1999. Integration of organ systems in avian osmoregulation. J. Exp. Zool. Part A: Comp. Exp. Biol., 283: 702-707. DOI: 10.1002/(SICI)1097-

010X(19990601)283:7<702::AID-JEZ8>3.0.CO;2-F 
10. Butler, D.G., J.H. Youson and E. Campolin, 1991. Configuration of the medial and lateral segments of the duck (Anas platyrhynchos) salt glands. J. Morphol., 207: 201-210. DOI: 10.1002/jmor.1052070211

11. Dunson, W.A., R.K. Packer and M.K. Dunson, 1971. Sea snakes: An unusual salt gland under the tongue. Science, 173: 437-441. http://www.ncbi.nlm.nih.gov/pubmed/17770448

12. Newbound, D.R. and J.E. Oshea, 2001. The microanatomy of the rectal salt gland of the Port Jackson shark, Heterodontus portusjacksoni (Meyer) (Heterodontidae): Suggestions for a counter-current exchange system. Cells Tiss. Organs, 162: 165-175. DOI: 10.1159/000047875

13. Fernandes, M. and Z. Gasparini, 2008. Salt glands in the Jurassic metriorhynchid Geosaurus: Implication for the evolution of osmoregulation in Mesozoic marine crocodyliforms. Naturwissenschaften, 95 : 79-84. DOI: 10.1007/s00114-007-0296-1

14. Fange, R., K. Schmidt-Nielsen and M. Robinson, 1958. Control of secretion from the avian salt gland. Am. J. Physiol., 195: 321-326. http://www.ajplegacy.physiology.org/cgi/content/a bstract/195/2/321

15. Cramp, R.L., N.J. Hudson, A. Holmberg, S. Holmgren and C.E. Franklin, 2007. The effects of salt water acclimation on neurotransmitters in the lingual salt glands of the estuarine crocodile Crocodylus porosus. Regul. Pept., 140: 55-64. http://www.ncbi.nlm.nih.gov/pubmed/17182121

16. Schmidt-Nielsen, K. and W.L. Sladen, 1958. Nasal salt secretion in the Humboldt penguin. Nature, 181: 1217-1218. DOI: 10.1038/1811217b0

17. Peaker, M., 1971. Avian salt glands. Philosophic. Trans. R. Soc. Lond. Ser. B. Biol. Sci., 262: 289-300. http://www.jstor.org/pss/2417130

18. Sabat, P., 2000. Birds in marine and saline environments: living in dry habitat. Rev. Chil. Hist. Nat., 73: 401-410. DOI: 10.4067/S0716078X2000000300004

19. Gray, D.A., C. Downing and N. Sayed, 1997. Endogenous plasma atrial natriuretic peptide and the control of salt gland function in the Pekin duck. Am. J. Physiol. Regul. Integrat. Comp. Physiol., 273: R1080-R1085.

http://www.ajpregu.physiology.org/cgi/reprint/273/ 3/R1080
20. Hughes, M.R., 2003. Regulation of salt gland, gut and kidney interactions. Comparat. Biochem. Physiol. Part A: Mol. Integrat. Physiol., 136: 507-524. DOI: 10.1016/j.cbpb.2003.09.005

21. Dunson, W.A., M.K. Dunson and R.D. Ohmart, 1976. Evidence for the presence of nasal salt glands in the roadrunner at the Coturnix quail. J. Exp. Zool., 198: 209-216. http://www.ncbi.nlm.nih.gov/pubmed/135819

22. Holmes, W.N., 1972. Regulation of electrolyte balance in marine birds with special reference to the role of the pituitary-adrenal axis in the duck (Anas platyrhynchos). Fed. Proc., 31: 1587-1598. http://www.ncbi.nlm.nih.gov/pubmed/4351367

23. Hildebrandt, J.P., 2002. Coping with excess salt: Adaptive functions of extrarenalosmoregulatory organs in vertebrates. Zoology, 104: 209-220. DOI: 10.1078/0944-2006-00026

24. Gerstberger, R. and D.A. Gray, 1993. Fine structure, innervation and functional control of avian salt glands. Int. Rev. Cytol., 144: 129-215. http://cat.inist.fr/?aModele $=$ afficheN\&cpsidt $=4739$ 456

25. Bennett, D.C. and M.R. Hughes, 2003. Comparison of renal and salt gland function in three species of wild ducks. J. Exp. Biol., 206: 3273-3284. DOI: 10.1242/jeb.00551

26. Oguri, M., 1964. Rectal glands of marine and fresh-water sharks: Comparative histology. Science, 144: 1151-1152. DOI: 10.1126/science.144.3622.1151

27. Kosztolanyi, A., T. Szekely, I.C. Cuthill, K.T. Yilmaz and S. Berberoglu, 2006. Ecological constrains on breeding system evolution: The influence of habitat on brood desertion in Kentia plover. J. Anim. Ecol., 75: 257-265. DOI: 10.1111/j.13652656.2006.01049.x

28. Gabe, M. and H. Saint-Girons, 1969. Histological data on the salivary glands of lepidosauriens. Memories of the National Museum on Natural History, 58: 1-112. http://www.maremagnum.com/index.php?option=c om_ricerca\&task=risult \&desiditem $=36121607 \mathrm{zzz}$ 